\title{
1. Introduction to Research Handbook on European Union Taxation Law
}

\author{
Christiana HJI Panayi, Werner Haslehner and Edoardo \\ Traversa
}

Writing a book on European Union (EU) tax law was never going to be an easy task, not only due to the diversity of areas covered by this subject but also as a result of the fast-paced changes in the area. EU tax law is perhaps one of the most dynamic areas of EU law. Notwithstanding de minimis harmonisation, for direct taxation, and more extensive framework-style harmonisation, for indirect taxation, the combined effect of the Commission's integrationist leanings with taxpayer proactiveness and the pursuit of litigation has led to the development of an impressive array of legal principles. Being supreme law, these principles permeate domestic tax systems and shape domestic tax rules, in variable intensities and with variable preemptive effects.

At the same time, EU tax law does not exist in a vacuum and is very much affected by developments in the sphere of international tax law. While there is no such thing as binding international tax law, through the medium of either EU hard law or soft law it is easy to see the influences of some high profile international tax developments. To the extent that they facilitate an integrationist agenda, such influences have helped shape the trajectory of EU tax law.

Our book tries to capture the essence of EU tax law by investigating the principles developed in a number of areas both in the context of direct and indirect taxation. We consider important issues and debates arising under the general principles that imbue this area as a whole but also in more specific areas, such as taxation of individuals, taxation of businesses, taxation of passive investment and taxation of the nonprofit sector. We also examine the state of the tax harmonisation debate in the more traditionalist areas of corporate taxation and VAT, but also consider more novel areas such as excise duties and environmental taxation. Tax competition, state aid and the impact of the international polemic against aggressive tax planning are also explored in this book. So are the more procedural but equally important topics dealing with cooperation between tax authorities, exchange of information, taxpayer rights and dispute resolution. The final part of this book examines the external dimension to EU tax law - not only as far the Treaty freedoms are concerned but also in the context of trade agreements and Association Agreements.

What is unique about this book is that the above topics are addressed by leading experts in their field in a comprehensive and unbiased manner. All the contributors examine the status quo in each area, offering valuable insights as to the existing debates, controversies and unanswered questions. They also set out the future research agenda in all these areas. ${ }^{1}$

1 In order to ensure internal consistency within each chapter, we have allowed our contributors the freedom to adopt the citation and referencing style of their choice. 


\section{Research handbook on European Union taxation law}

In Chapter 2, Georg Kofler examines the EU's power to regulate taxation, in light of its competences under direct tax law. It is shown that subject to the principles of subsidiarity and proportionality, the Union seems to have broad theoretical power for internal harmonization measures in the direct tax area in so far as is necessary for the establishment and the functioning of the internal market. That internal market is historically viewed both through the lens of freedoms rights with the aim of removing tax distortions, as well as through the lens of practices of tax evasion and tax avoidance with the aim of making the system more robust and resilient to aggressive tax planning. The author argues that (future) internal harmonisation can lead to the emergence of external treatymaking powers of the Union which may even become an exclusive competence and have (yet largely unexplored) impact on the Member States' bilateral tax treaties with third countries. He concludes that in both the internal and the external sphere, the progress and limits of Union action are, however, not only questions with regard to the existence of competence (lack of which can be scrutinised by the Court of Justice), but largely political ones because of the unanimity requirement.

In Chapter 3, Gianluigi Bizioli and Ekkehart Reimer examine the principles of neutrality, equality and ability to pay and their impact on the EU legal order. In the first part, the authors consider the theoretical meaning and the structure of those principles, and review the historical and current role of ability to pay under Member State tax systems. At the EU law level, it is shown that both the fundamental freedoms and secondary EU tax law have incorporated concepts of neutrality, equality and ability to pay under their normative framework. The authors conclude with an outlook on the link between EU tax approximation and public goods provided by the different Member States.

In Chapter 4, Edoardo Traversa explores the content and function of the principles of territoriality and prohibition of abuse of rights in EU tax law. Territoriality is a well-known concept in international (tax) law but less so in EU law, namely because the EU has no autonomous taxing powers. Apart from the notable exception of the Customs Union and, to a lesser extent, the EU common VAT system, there is indeed no legal recognition of the EU territory as a single area for tax purposes. Territoriality, therefore, continues to refer to the taxing powers of the Member States, in particular as a justification to a restriction to the fundamental freedoms in the case law of the Court of Justice. Despite being conceptually distinct from the principle of territoriality, the prohibition of abuse of rights, a general principle applicable to all areas covered by EU law, serves a similar purpose in European tax law. In the case law of the Court of Justice dealing with the application of the fundamental freedoms on Member States' tax systems, both principles are allowed as justifications and reflect the need to consider the financial interests of the Member States in an internal market where taxation remains largely unharmonised. As such, the gradual emergence of justifications based on the balanced allocation of taxing powers and on coherence offers interesting possibilities for future research.

In Chapter 5, Rita Szudoczky examines the relationship between primary and secondary EU law. While primary and secondary Union law can interact with each other in numerous ways, the fact that there is a hierarchical relationship between them stems from the basic constitutional order of the Union. Despite this constitutional tenet, the case law of the Court of Justice is inconsistent as regards the relationship of primary and secondary law. What clearly stands out from this case law is the reluctance of the Court of Justice to exercise an effective substantive review of the legality of secondary legislation in light of primary law and thereby enforce the hierarchy between the two. This chapter examines different lines of the case law - in general and with a special focus on the tax case law - in order to demonstrate how the Court of 
Justice avoids directly addressing a conflict between primary and secondary law. It is argued that the Court of Justice needs to strengthen the constitutional review of secondary law while at the same time maintain the institutional balance within the Union. It is especially important to do this in the area of taxation, where, on the one hand, the degree of harmonisation gradually increases, and, on the other, harmonisation measures expand beyond their traditional sphere.

In Chapter 6, Christiana HJI Panayi examines the relationship between EU and international law in the area of tax law. Certain important aspects of this relationship are addressed, mostly in the context of tax treaties between Member States and between Member States and third countries. The chapter also analyses the development of Union competences in the area of external fiscal policy. It is shown that even though Member States have technically kept their competences over direct taxation, the combined effect of negative integration and expansive secondary legislation has led to a situation where the Union has a great say over what can be included in tax treaties that Member States enter between themselves and with third countries. However, in the absence of clear rules, the line between what is and what is not permissible is beginning to be blurred. It is shown how this is exacerbated by the development of soft law in the context of the EU's external fiscal policy, leading to some interesting results.

In Chapter 7, Frans Vanistendael assesses the principles of freedom of movement and neutrality applied to taxation in light of the main objectives of the EU as formulated in the TEU and TFEU, that is, the establishment of the internal market. First, the chapter provides an illustration of the causes of the present inconsistencies in tax policy deriving from the current constitutional framework and allocation of powers between the EU and the Member States. Second, the chapter proposes a possible resolution of these inconsistencies in order to solve cases of discrimination and double economic and juridical taxation arising from the cumulative application of national tax regimes, based on the objectives of competitive export tax neutrality and competitive import neutrality. Finally, a link is made between the achievement of these goals and the need to reform the EU framework as regards harmonisation of corporate taxation and financing of the common EU budget.

In Chapter 8, Niels Bammens deals with the case law of the Court of Justice on tax benefits granted by domestic individual income tax systems for personal and family circumstances. He explains that in situations where a taxpayer's personal and economic ties are spread over different states, personal and family circumstances may not be fully taken into account. This is because source states may restrict the entitlement to personal and family-related tax benefits to their residents, while the home state may be reluctant to fully grant such benefits if it is unable to tax the taxpayer's entire income. The author reviews the case law in this area and questions whether the free movement provisions require tax benefits concerning personal and family circumstances to be granted in crossborder situations, and if so, which of the states involved is required to do so.

Chapter 9 is written by Alexandre Maitrot de la Motte and is devoted to the taxation of business in the EU and the fundamental freedoms. This chapter reviews the general approaches to comparability of foreign companies, permanent establishments and subsidiaries, the limits to the requirement of equal treatment and the question of economic double taxation. The author argues that, following established case law, there are two sets of uncertainties: what situations should be compared, and how they should be compared. According to the author, more rigorous criteria should be adopted in making comparisons. Other issues discussed by this author are the territorial scope of the protections offered by EU law and the existence of a most favoured nation tax clause in EU law. It is also questioned whether economic double taxation 
is a restriction to fundamental freedoms and whether, in view of the unity of the single market and its proper functioning, it should be regarded as such.

In Chapter 10, Johanna Hey reviews more specific problems relating to the taxation of businesses in the EU. The chapter analyses and criticises the case law of the Court of Justice on crossborder loss recognition and on exit taxation. It is shown that notwithstanding the differences in the case law, there is a common thread, in that a territorial allocation of taxing rights is contradictory to the internal market. Johanna argues that the Court of Justice lacks legal standards to establish compromises at the level of the proportionality test and the problem is not just one of lack of harmonisation, but, indeed, of revenue transfers between the Member States. As far-reaching harmonisation in this area is not forthcoming, one has to accept and appreciate the limited achievements of the Court of Justice in equalising crossborder and domestic treatment.

In Chapter 11, Marjaana Helminen discusses the impact of EU tax law on the tax treatment of passive investment income, such as dividends, interest and royalties. In addition to the two corporate tax directives, that is, the Parent-Subsidiary Directive and the Interest and Royalties Directive, it is explained that the fundamental freedoms have had a huge impact on the powers of Member States to tax crossborder investment income. Despite the large number of cases litigated in these area, there are still many open issues. This chapter discusses these issues both from the perspective of intra-EU situations and from the perspective of situations involving non-Member States.

In Chapter 12, Sigrid Hemels examines the impact of EU law on charities. Because of their important role in civil society, charities are often granted a special status in national tax legislation. Many charities undertake activities abroad and come in the realm of EU law, for example, because of crossborder investments, fundraising activities and competition with foreign charities. Tax legislation for charities is, however, not harmonised in the EU and varies widely. In the past 15 years, EU law and especially the fundamental freedoms have had a significant impact on the direct tax position of charities. The author critically analyses these developments.

In Chapter 13, Malcolm Gammie reviews initiatives on corporate tax harmonisation that arose in the formative years of the Community. The struggle for progress was obvious, as over the years with which this chapter is concerned there was no political will among Member States to achieve any significant progress towards corporate tax harmonisation. This was notwithstanding the fact that early studies clearly identified the negative implications of such nonharmonisation for the establishment of the single market. The author describes how the Community in this period had not developed to a point at which the necessary foundations were in place to make some action a political imperative. He argues that a single market essentially imposes particular solutions to the adoption and continued existence of a corporate income tax. In this respect, political support for particular tax measures is more likely to follow the economic imperatives imposed by the developing market than it is to follow the academic analysis of economists and the recommendations of expert committees.

In Chapter 14, Luca Cerioni continues the discussion and examines priorities pursued by the EU in the area of corporate tax harmonisation since 2001. He shows that the EU's priorities appear to have switched from the removal of crossborder tax obstacles to the fight against tax avoidance and harmful tax competition. Cerioni argues that the legislative measures that have been introduced for this purpose risk targeting structures in the absence of wholly artificial arrangements as intended under the case law of the Court of Justice. Furthermore, such legis- 
lative measures may be ineffective in tackling forms of aggressive tax planning allowed by the kind of tax competition that has been consistently regarded as 'fair'. The author argues that, on the basis of legislative measures enacted, the EU may have overreacted against tax avoidance but underreacted against its ultimate cause, that is, against harmful tax competition. A significant challenge arises for future research in order to find the best way to achieve coordination of measures which counter tax avoidance and harmful tax competition.

In Chapter 15, Charlène Herbain investigates the origins and principles guiding the implementation of VAT in the EU. First, she attempts to clarify the historical foundations of the EU VAT common system, examining the first reforms aimed at implementing turnover taxes in European, but also non-European countries. In the second part, the contribution identifies and critically discusses characteristics of this tax, such as neutrality, simplicity, nondiscrimination and fairness, which helped make it so successful. This is notwithstanding the political and procedural obstacles to harmonisation of taxation within the EU - in particular the requirement of unanimity.

In Chapter 16, Marie Lamensch examines specific issues relating to the VAT system. The harmonisation of the EU VAT system was one of the prerequisites for the setting up and proper functioning of a common market. The harmonisation process that has taken place is quite remarkable as the VAT legislation in each Member State is roughly identical from a regulatory perspective. However, in this chapter, the author argues that the sustainability of the harmonised VAT system is in danger due to several factors, including the unanimity requirement enshrined in Article 113 of the TFEU, which in practice prevents a much required legislative modernisation of the EU VAT system. The author also examines the absence of harmonised administrative practices and of a dispute settlement system, the increased reliance on administrative cooperation between the Member States without much transparency and the failure to investigate new technologies as a means to support collection and enforcement. She argues that further research is necessary to address these shortcomings sooner rather than later.

In Chapter 17, Alice Pirlot explores whether and how EU law has shaped the use of environmental tax measures - including environmental taxes and environmentally driven taxes and tax incentives - in the EU, drawing on existing literature on the topic. The author shows that EU law has shaped and continues to shape the development of environmental tax measures both at the level of the EU and at the level of the Member States. It is argued that at EU level, the institutional framework has not really helped in the enactment of environmentally-driven taxes. The analysis of the historical development of EU provisions surrounding energy taxation illustrates this point. So far, the Energy Taxation Directive remains largely disconnected from the EU's climate policy, including the EU Emissions Trading Scheme. Secondly, EU substantive law has had an ambiguous impact on Member States' environmental tax policy. On the one hand, EU substantive law has been interpreted by the Court of Justice in a way that encourages Member States to adopt tax measures that are environmentally driven. Indeed, the environmental purpose of Member States' tax measures seems to play a positive role in the assessment of their compatibility with EU law, including State aid provisions, the fundamental freedoms and the Energy Taxation Directive. On the other hand, in some instances, EU law strictly limits Member States' ability to adopt environmentally driven tax measures. Moreover, taxes can be classified as environmental taxes for statistical purposes, even when their objective is not to protect the environment.

In Chapter 18, Ana Paula Dourado analyses the concepts of aggressive tax planning and harmful tax competition that have increasingly influenced EU tax policy over the past 20 
years. The chapter first sets out to examine the meaning of aggressive tax planning in light of relevant EU policy documents and legislation such as the ATAD and the Directive on Administrative Cooperation and their interaction with international efforts coordinated at the level of the G20/OECD pursuant to the BEPS project. Going beyond a mere assessment of the legal texts, the author also explores jurisprudential developments concerning aggressive tax avoidance and legislative proposals, especially as triggered by the challenges of digitization. The chapter then focuses on the soft law instruments developed by the EU to respond to harmful tax competition, in particular the 1997 Code of Conduct and more recent efforts to combat tax havens via the EU blacklist. The author concludes that, though distinct, the concepts of aggressive tax planning and harmful tax competition are closely related in that the former is at least partly encompassed in the latter.

In Chapter 19, Richard Lyal analyses the basics of the fiscal State aid rules applied in the EU, and the potential scope for tension between these rules and Member State sovereignty in tax matters. As the questions explored here are among the most relevant and hotly debated in academic literature as well as recent case law, the chapter starts with an excellent introduction to this provision. After detailing the four criteria to establish the existence of State aid in accordance with Article 107 TFEU with reference to the key judicial developments, the chapter delves into the doctrinal difficulties regarding fiscal State aid. The author clearly identifies the areas in need of further clarification, such as the determination of the reference framework to establish selective advantages and the justification of differences under the rather vague concept of the 'nature or general scheme of the tax system'. Beyond these uncertainties, the author identifies further important issues for future research such as the relationship between State aid law and Member States' bilateral agreements as well as that between State aid law and national antiabuse provisions, and the distinction between individual aid and aid schemes.

In Chapter 20, Werner Haslehner addresses the interaction of State aid law with transfer pricing rules. A number of high-profile investigations into transfer pricing arrangements approved by Member States' authorities, including for companies such as Amazon, Apple and Starbucks, has sparked fierce debate over the existence of an EU principle of arm's length taxation and its possible content. The chapter examines this debate and issues pertaining to the relationship between State aid law and double taxation treaties, justifications on the basis of providing double tax relief or protection from tax avoidance, and the scope of administrative discretion that State aid law needs to accord in a highly technical area of national law such as transfer pricing.

In Chapter 21, Roland Ismer and Sophia Piotrowski explore the relationship between fiscal State aid and the fundamental freedoms. Both are fundamental principles that underpin the internal market which is at the core of the EU. Both prohibit discriminatory practices by Member States. The authors describe the conditions and criteria applied in the context of each discrimination rule and argue that they are, in fact, subject to limited metaconvergence: even where the principles underlying each rule appear the same, such as the principle of nondiscrimination or the principle of proportionality, their concrete meaning is subtly different under the fundamental freedoms on the one hand, and State aid law, on the other. The authors analyse the question of a potential hierarchical order between the two. After a thorough discussion of existing case law and literature, they argue that fundamental freedoms ought to prevail in the majority of cases, where their application resolves the discrimination at issue. At the same time, State aid rules often take precedence before national courts. Concluding their analysis, the authors then point towards key differences in the procedure of enforcing both sets of rules. 
In Chapter 22, Ilse De Troyer examines EU law aspects of tax procedure, in particular administrative cooperation and recovery assistance between Member States. The author starts with an overview and description of the relevant secondary law rules pertaining to the topic and identifies the important research questions in the field. She focuses on the following key aspects of that research: the changing relationship between Member States' tax authorities, the limits imposed by legal principles on the crossborder exchange of information, concerns about the system's efficiency and whether the exchange of information exists merely to the benefit of the tax administration or can also be enforced on the taxpayer's behalf.

In Chapter 23, Roman Seer and Sascha Kargitta describe the different types of tax information exchange, their respective advantages and disadvantages and the underlying legal principles. The chapter focuses on the bilateral information exchange clauses in double tax treaties as provided for by Article 26 of the OECD Model Tax Convention and the OECD Model Tax Information Exchange Agreement. There is also an examination of multilateral approaches such as the Convention on Mutual Administrative Assistance in Tax Matters. The authors examine the EU efforts to expand automatic exchange of information, largely modeled after the US FATCA, through the 2011 Directive on Administrative Cooperation and its various subsequent amendments. The authors analyse legal concerns derived from the evolving tax information exchange system, in particular the possible violation of universally existing data protection provisions. While the authors acknowledge the need for effective information exchange, they argue that the use of exchanged information by the participating tax authorities may, at times, go beyond what is necessary. In particular, they point to the risk of the information exchanged not being processed properly, but instead being piled up in administrative IT systems that may amount to unconstitutional 'data cemeteries'.

In Chapter 24, Katerina Perrou explores taxpayer rights arising from the EU Charter of Fundamental Rights. Although the Charter primarily applies to the bodies and institutions of the EU itself, the Charter crucially also applies to Member States when they 'implement Union law'. As the Court of Justice has interpreted this phrase in an ever expanding manner, and as more and more secondary law affects domestic taxation, the latter comes increasingly within the scope of the Charter rights, such as the right to privacy, the right to data protection, the right to an effective legal remedy and the right to a fair trial. The chapter devotes a significant part of its analysis to the Charter's scope and its potential impact, before discussing the most relevant case law from recent years. It concludes with an outlook on matters for future research, such as the continuously developing relationship between the Court of Justice and the European Court of Human Rights.

In Chapter 25, Katerina Perrou examines tax dispute resolution in the EU with an emphasis on taxpayers' participation in the process. As bilateral tax (treaty) disputes are traditionally resolved at an administrative (intergovernmental) level, the lack of taxpayer participation can impact procedural rights protected in the European Convention of Human Rights and the EU Charter of Fundamental Rights, such as the right to an effective remedy and the right to a fair trial. The chapter analyses the tension between the practice of dispute resolution and the protection of the aforementioned rights and the implications of the recent adoption of the Tax Dispute Resolution Directive. A second key problem is also analysed: under what circumstances does the autonomous EU law and the supreme position of the Court of Justice allow the existence of dispute resolution mechanisms that - while standing outside the boundaries of its judiciary - may affect EU law? 
In Chapter 26, Karoline Spies reviews the external aspects of the fundamental freedoms. The author explains that the fundamental freedoms prohibit restrictions on the movement of persons, goods, services and capital in the internal market. Only in limited areas do the freedoms extend their effects to movements in relation to third countries. This chapter addresses under which circumstances third country situations may be covered by the fundamental freedoms, in particular the free movement of capital, and which limitations may apply in the area of tax law. Special focus is given to the case law of the Court of Justice on the free movement of capital, which has greatly evolved over the years.

In Chapter 27, Raymond Luja examines trade and investment agreements, a field where competences have gradually shifted from the Member States to the EU. He reviews the differences in treatment of goods and services under trade rules in areas such as nondiscrimination and subsidies. The author explains that taxation as a policy instrument is largely carved out of investor protection agreements, although the latter might be called upon to address issues of, for instance, state aid recovery. The author argues that trade agreements are in need of substantial revision so as to accommodate the destination-based taxation of the digital economy. The author also considers some very interesting trade-related issues regarding the digital services taxes and the blacklisting of noncooperative jurisdictions.

In the final chapter to this book, Chapter 28, the impact of EU Association Agreements on Member States' corporate tax systems is explored by Daniël Smith. It is shown that, to some extent, the case law of the Court of Justice on fundamental freedoms relating to intra-EU corporate investment situations also applies to corporate investments made between Member States and Association countries. The author argues that in the field of company taxation, broadly, the free movement provisions under the Association Agreements (notably the free movement of capital) can be seen as complementary to the free movement of capital under Article 63 TFEU. It is, furthermore, predicted that the impact of the free movement provisions included in Association Agreements will increase in the future.

Overall, in exploring several of the above topics, it becomes obvious that the objectives of EU tax integration are sometimes blurred. Often there are internal tensions with other competing themes or sources of law. For example, to what extent are the efforts for further tax integration (and harmonisation) skewed in favour of (large) corporates rather than the European citizen/worker, the family unit and the charity sector? Furthermore, to what extent do these efforts take into account taxpayer rights and remedies? Moreover, how can one align older initiatives to remove tax obstacles to crossborder movement and important case law of the Court of Justice with the more recent protectionist initiatives to protect the tax base of Member States and tackle aggressive tax planning? How much and what type of (Member State) tax competition is tolerated in the EU and how does this affect the overall competitiveness of the EU?

What also becomes obvious is the growing internationalisation of EU law and the EU's outward-looking fiscal policy focus; again, sometimes leading to inherent tensions. To what extent are tax treaties protected and to what extent have common EU rules preempted and replaced Member States' tax treaty policies? To what extent are competences respected when it comes to the development of the EU's external fiscal policy? What is the influence of international organisations such as the OECD or the WTO in the development of EU tax law and what are the implications of this? Has the EU itself become an important player in the international tax arena, influencing norm setting? Or does the largely unharmonised environment, partly as a result of institutional limitations and the unanimity rule, prevent the EU from reaching its full potential as an important global tax player? 
These and many other questions arise in the context of our authors' analyses, setting out the agenda for future research. In fact, this is an important aim of our book: to show not only the progress so far, but also the limitations of the EU legal analysis in various areas of tax law and, whenever possible, to make suggestions as to what practical steps should be taken, backed up by solid principles. We hope that our book will become an important reference point for all tax scholars but also for practitioners, government officials and students who wish to navigate this very complex area of law. 